\title{
„LAI WISHFUL THINKING REZULTĀTĀ BŪTU VIENA PILSĒTA“ — NARATĪVS PAR DZIVI STARP DIVIEM LAIKMETIEM VALKAS-VALGAS DVĪṆU PILSĒTĀ
}

\author{
Sanita LAZDIN̦A \\ Rēzeknes Tehnoloǵiju akadēmija
}

\section{Ievads}

Raksta pamatā ir pētījums, kurš Latvijas un Igaunijas pierobežas pilsētās Valkā un Valgā tika veikts 2014.-2015. gadā, lai izzinātu valodu lietojumu gan publiskajā telpā (lingvistiskā ainava), gan iedzīvotāju mutvārdu saziņā (īpaši starp Valgas un Valkas pusē dzìvojošajiem igauņiem, latviešiem un krieviem), kā arī - lai pētìtu abās pusēs dzīvojošo cilvēku pierobežas stāstus. Šajā rakstā ir izvēlēta tieši šo stāstu (naratīva) analīze, iedziḷinoties stāstu saturā (kuri ir bijuši tie pagrieziena punkti, kas visvairāk ietekmējuši stāstītāja dzīvi), paša stāstìtāja reprezentācijā citiem (kāda un kā tiek uzsvērta runātāja identitāte) un stāstījuma noformējumā (naratīva aktā).

Pētījuma galvenie jautājumi ir iekodēti raksta nosaukumā: kā stāstìtāija stāsti atspoguļo translokalitāti dažādos dzīves posmos (konkrētās stāstītājas kontekstā — arī dažādās politiskajās iekārtās) un vai translokalitāte izpaužas arī valodā, proti, kurās situācijās un kāpēc notiek pārslēgšanās no viena valodas koda uz otru jeb koda maiņa. Pēdējās desmitgades laikā sociolingvistikā un lietišķajā valodniecībā paralēli terminam koda maina (code switching) arvien biežāk tiek lietots arī termins translanguaging, kuru latviešu valodā varētu apzīmēt kā kodu variēšana. Abi termini semantiski ir ḷoti tuvi, tomēr jaunā termina (translanguaging) lietotāji norāda uz niansētām atškirin̄bām nozīmes ziņā, liekot uzsvaru vairāk uz poststrukturālās paradigmas ietekmi valodu pētījumos un apguvē. Piemēram, valodnieki (García 2009; Blackledge, Creese 2010; García, Wei 2014; Mazak, Carroll 2017 u. c.) uzsver, ka, pretēji uzskatam par divām nošķirtām lingvistiskām sistēmām, kas raksturīgas bilingvāliem cilvēkiem, ir jārunā par vienotu, savā starpā integrētu valodu lingvistisko repertuāru, kurš piemīt bilingviem. Ar šo apgalvojumu tiek akcentēta atziņa, ka bilingvāls runātājs nevis maina kodus, bet tos variē atbilstoši situācijai noteiktā kontekstā, izvēloties kādu noteiktu daḷu no sava lingvistiskā repertuāra. Tātad — vairāku valodu struktūras smadzenēs nav tik nošķirtas jeb norobežotas. Plašākā nozīmē jēdziens translanguaging tiek lietots arī izglìitības diskursā, ar to apzīmējot kādas valodas apguves procesu, kura laikā tiek izmantotas vairākas apguvējam zināmās valodas, proti, tās tiek variētas, attīstot dažādas valodas prasmes, piemēram, lasot vienā valodā, bet par to stāstot citā.

Raksta nosaukumā ir izmantots citāts no citas, ne šajā rakstā aplūkotās, respondentes teiktā (datu bāzē ieraksts 062M), kas visspilgtāk raksturo šì pētịjuma 
profilu: mani droši vien tāpēc ir pieñèmuši darbā, lai (---) wishful thinking rezultātā būtu viena pilsēta. Pavisam nopietni, divās valstīs.

Rakstu veido četras nodą̧as un secinājumi: pētījums sākas ar ievadu, kam seko otrā nodaḷa - neliels vēsturisks ieskats par Valkas un Valgas kā vienas pilsētas pastāvēšanu līdz divu neatkarīgu valstu - Latvijas un Igaunijas - dibināšanai, par robežu izveidošanu un atcelšanu, robežkontroli dažādos 20.-21. gs. laika posmos. Vēsturiskais fons ir nepieciešams, lai labāk saprastu naratīvā paustos dzīvesstāstus, aprakstītos notikumus un emocijas, kā arī pamanītu vēsturisko notikumu un politisko lēmumu ietekmi uz perifērijā, divu valstu pierobežā, dzìvojošo cilvēku ikdienu. Trešajā nodạ̦ā ir izklāstìta pētījuma metodoloǵija, proti, naratīva jēdziens un naratīva analīzes struktūra, naratīva interpretācijā lietotie jēdzieni (translokalitāte, kodu pamīšus lietojums, deiktiskās norādes). Teorētiskajā dạ̧ā pieteiktā naratīva analīzes struktūra ir ņemta par pamatu ceturtās nodalias izkārtojumam, proti, tajā atsevišķi ir raksturoti visi trīs struktūras komponenti: pats stāsts, stāstītājs un stāstījums (attiecīgi: 4.1., 4.2. un 4.3. apakšnodaḷas). Raksta noslēgumā ir doti būtiskākie secinājumi, kas izriet no š̀ pētīiuma.

\section{Vēsturiskais konteksts}

Vēsturiski Valka un Valga ir bijusi viena pilsēta, kurai pilsētas tiesības 1584. gadā piešksīra poḷu karalis Stefans Batorijs. Rakstos tās nosaukums parādījies kā Walk, Walka, Валкъ. Valka ir pilsēta, kurā dzīvojuši dažādu tautību pārstāvji, bet majoritāte vienmēr ir bijuši latvieši un igauņi. Piemēram, 19. gs. beigās, proti, 1897. gadā, pilsētā (ieskaitot priekšpilsētas) tiek minēts šāds etniskais sastāvs ${ }^{1}$ : latvieši (40,7 \%), igauņi (32,9\%), krievi (11,1 \%), vācieši (10,4 \%), pārējie (4,9\%). Par latviešu un igauņu ciešo kopā dzīvošanu šajā teritorijā liecina arī kultūras un izglīî̄bas dzìve, kas abām etniskajām kopienām tika organizēta kopīgi. Spilgtākais pierādījums tam ir Vidzemes draudzes skolu skolotāju seminārs (1839-1890), kurš 1839. gadā tika dibināts Valmierā, bet pēc 10 gadiem (1849) pārcelts uz Valku. Par galveno semināra uzdevumu tika izvirzìts: sagatavot Vidzemes latviešu un igauņu apgabala draudzēm skolotājus. Vēstures materiāli atklāj arī to, ka pēc nacionālās atmodas 19. gs. otrajā pusē un 20. gs. sākumā gan latviešiem, gan igauņiem tika novērota spēcīgāka nacionālā pašapziņa un zināma konkurence pilsētas politiskajā pārvaldē. Piemēram, 1917. gada 16. jūlijā notika Valkas pilsētas domes vēlēšanas, kur no 40 domnieku vietām latvieši ieguva 17, igauņi -16 , bet cittautieši (krievi, pol̦i, ebreji) - 7 vietas. Par pilsētas galvu pirmo reizi ievēlēja latvieti Kārli Aleksandru Ozoliņu. Uz pilsētas

1 Nodaḷa „Vēsturiskais konteksts“ izmantoto vēstures datu pamatā ir Valkas novadpētniecības muzeja materiāli. 
galvas amatu kandidēja arī igaunis Dr. A. Metuss. Kad viņš vēlēšanās zaudēja, igauņi demonstratīvi atteicās piedalīities pilsētas pārvaldē, tāpēc arī pārējos amatus sadalīja starp latviešiem un cittautiešiem (pēc Valkas novadpētniecības muzeja materiāliem).

Kad 1918. gadā tika dibinātas abas neatkarīgās valstis, aktuāls kḷuva jautājums par pilsētas (Valkas) sadalīšanu starp Latviju un Igauniju. Nespējot savstarpēji vienoties, kurai republikai piederēs kura pilsētas daļa, talkā tika aicināti eksperti no malas. „1920. gada 1. jūlijā, nosakot robežu starp jaunajām Latvijas un Igaunijas neatkarīgajām valstīm, sabiedroto škīiēitiesa angḷu pulkveža S. G. Talenta vadībā pieņēma lēmumu sadalīt Valku. Radās Latvijas Valka un Igaunijas Valka (tagad Valga). Igaunija ieguva praktiski visu vecās Valkas vēsturisko centru un pilsētas lielāko daḷu. " (Valkas novada dome 2014: 13)

Robežas izveidošana starp jaunajām valstīm simboliski veidoja norobežošanos starp latviešiem un igauņiem arī politiskajā, ekonomiskajā un kultūras dzīvē, radot divu suverēnu pilsētu pārvaldes struktūras un iekḷaujoties jaunizveidoto nacionālo valstu kontekstā. Baltijas valstu militārā okupācija, ko 1940. gadā īstenoja PSRS, noteica arī robežas likvidēšanu Valkā, paredzot brīvu pārvietošanos bijušo neatkarīgo Latvijas un Igaunijas valstu iedzīvotājiem. Kḷūstot par padomju republikām un zaudējot savu suverenitāti un patstāvību politisko jautājumu risināšanā, abu valstu robežpilsētā Valkā-Valgā tās iedzīvotāju sadzīvē robežas arī sāka saplūst. Veidojās situācijas, kad Latvijas iedzīvotāji strādāja Igaunijas pusē (Valgā), bet vakarā atgriezās mājās Latvijas pusē (Valkā), un otrādi (izvērstāku situācijas aprakstu sk. tāāāk 4.1. nodaḷā). Šajā periodā 50 gadu laikā izveidojās stabili iedzìvotāju paradumi, emocionāli un pragmatiski iemesli pārrobežu dzìves organizēěanā kā sociālajā, tā individuālajā sfērā.

Abu valstu neatkarības atjaunošana sekmēja, protams, arī valstu robežu atjaunošanu, un tā 1990. gadā valsts robeža tika atjaunota arī Valkā-Valgā. Pirmajos gados vietējo iedzīvotāju sadzīvē tas radīija pamatīgas jukas; kā apliecina interviju ieraksti, lēmumi, kuri Rīgā un Tallinā tika pieņemti nacionālajā līmenī, bija neadekvāti praktiskajā izpildījumā tādās robežpilsētās kā Valka-Valga (sīkāk sk. 4. nodạ̦ā). Fiziska robeža (ar robežkontroles punktiem un pasu pārbaudi) abās pilsētās pastāvēja, līdz Latvija un Igaunija pievienojās Šengenas zonai. Formalitātes, kas bija saistītas ar robežas šķērsošanu, pilnībā izzuda pēc 2007. gada 21. decembra (Latvijas Republikas Ārlietu ministrija 2007).

\section{Pētījuma metodologiija}

Veicot pētījumu Valkā un Valgā, tika iegūti daudzveidīgi pētījuma dati: fotografētas valodas zīmes publiskajā telpā (lingvistiskā ainava), intervēti vietējo pašvaldības un izglīîibas iestāžu darbinieki, Latvijas-Igaunijas institūta direktore, tūrisma informācijas biroja darbinieces u. c. (kopā - 13 intervijas, interviju 
ierakstu kopējais garums: 7 h 17 min). Sākotnēji plānotās dal̦ēji strukturētās intervijas atsevišksu interviju laikā pārauga respondentu dzìvesstāstos, līdz ar to pētījuma laikā divos gadījumos (ar Latvijas-Igaunijas institūta direktori un Valkas pirmsskolas izglìtības iestādes psiholog̣i) strukturēta intervijas gaita tika nomainīta ar abu stāstītāju naratīvu ierakstu. Šajos dzīvesstāstos atklājās noteiktu sociopolitisko apstākḷu ietekme uz lokālās kopienas dzīvi pierobežā, tostarp, uz valodu lietojumu. Tajā pašā laikā arī pašu naratīvu valoda atspogulojo pārmaiņas, kas bija notikušas sabiedrībā.

Šajā rakstā padziḷināti tiks analizēts Valkas pirmsskolas izglìitības iestādes psiholoğes naratīvs, kurš tika ierakstīts 2014. gada oktobrī (ieraksta brīdī respondentes vecums bija 50 gadi). Tā kā ieraksts tika veikts vairākās tikšanās reizēs, ierakstu transkripti ir noformēti četrās daḷās ar kodiem: 054M, 055M, 056M, 057M. Šajā rakstā pamatā ir izmantota ierakstu transkripcija no personīgās interviju datu bāzes (13 interviju audioieraksti un transkribētie teksti) ar sadą̧as numuru 054M, nedaudz arī - no 056M. Salīdzinājumam un pierobežas situācijas fona dzị̄ākai izpratnei ir dots arī fragments no intervijas ar LatvijasIgaunijas institūta direktori (ieraksts veikts 2014. gada oktobrī; transkribētais teksts datu bāzē ar numuru: 060M).

Stāstījuma izpētē ir izmantota naratīva analīze (Gimenez 2010), pētījuma veikšanai izvirzot divus pamatjautāijumus: 1) kā stāstītāja un viņas stāsti atspoguḷo translokalitāti dažādos viņas dzīves posmos; 2) kurās situācijās un kā šajā naratīvā ir vērojama arī valodu robežu šķērsošana?

Iegūto datu analīzē un interpretācijā nozīmīga ir tādu pamatjēdzienu kā translokalitāte, kodu variēšana (translanguaging), deiktiskās norādes (deixis) un naratīvs izpratne. Savukārt teorētiskais pamatojums ir atrodams šādās teorijās: lingvistiskā etnogrāfija, naratīva analīze un multimodālā analīze (runas paralingvistiskais raksturojums, emocijas, kas izskan naratīvā).

Tālāk īsumā tiks aplūkoti gan minētie pamatjēdzieni, gan būtiskākās atziņas no teorijām, kas veidojušas pamatu iegūto datu interpretācijai.

Ar translokalitāti (translocality) teorētiskajā literatūrā tiek skaidrota robežu šḳērsošana - pāreja no vienas lokālās pierobežas teritorijas otrā (Greiner, Sakdapolrak 2013). Translokalitātei piemīt divas perspektīvas: ǵeogrāfiskā jeb telpiskā un sociālā - cilvēku dzīves telpa, veids, kā viņi organizē savu sociālo dzīvi, mijiedarbību ar citiem šajā pierobežas teritorijā (turpat). Līdz ar to translokalitātes jēdziens tiek izmantots, lai aprakstītu sociotelpisko dinamiku, proti, š̄i pētījuma kontekstā, - kā robežu šksērsošana ir ietekmējusi vai vēl aizvien ietekmē iedzìvotāju ikdienu, sociālo tīklošanos citam ar citu abu valstu (Igaunijas-Latvijas) pierobežā, viņu identitāti.

Vēl viens jēdziens, ar kuru angḷ valodā tiek apzīmēts pārejas, robežu šḳērsošanas process (tikai-lingvistisko robežu), ir translanguaging. Tā konceptuālā nozīme tiek saistīta ar pāreju no vienas valodas citā vienas runas situācijas laikā 
(vairāk sk. ievadā). Tāda spontāna pāreja no vienas valodas otrā ir raksturīga bilingvāliem runātāiiem un netiek saistīta ar nepietiekamu kādas valodas kompetenci, tieši otrādi - ar kompetenci vairāk nekā vienā valodā un citas valodas vārdu vai izteikumu izmantošanu, lai precīzi atdarinātu kādu runas aktu, citētu, lai izmantotu citu valodu kā stilistisko marķieri u. tml. Šis koncepts teorētiskajā literatūrā norāda uz atziņu, ka indivīds savu divu vai vairāku valodu lingvistisko repertuāru izmanto kā resursu, ar kura palīdzību runas akta laikā tiek likti noteikti uzsvari, ne vienmēr atzīstot valodu robežas (Blackledge, Creese 2010). Līdz ar to latviešu valodā jēdzienu translanguaging, kā tas tika minēts ievadā, varētu apzīmēt: vairāku valodu pamīšus lietojums jeb kodu variēšana (sk. arī Lazdiņa 2017). Šāda kodu variēšana nedaudz ir vērojama arī rakstā analizētajos naratīvos, tāpēc viens no izvirzìtajiem pètījuma jautājumiem - noskaidrot, kurās situācijās stāstītāja sarunas laikā pārslēdzas no vienas valodas uz citu.

Jēdziena naratīus skaidrošanai visbiežāk tiek izmantoti vārdi: stāstījums, dzīvesstāsts, dzīves vēsture (life (hi)story), mutvārdu vēsture. Precīzākais ekvivalents šim jēdzienam droši vien būtu - dzīvesstāsts, kurš kādam izstāstīts un kāds ir veicis tā pierakstu. Par dzivesstāstu izpēti savā promocijas darbā ir rakstījusi B. Bela-Krūmiņa, norādot, ka ,dzīvesstāstu izpētē izškịir trīs pieejas, kuras izriet no autobiogrāfijas strukturālā iedalījuma ,autos“ (patîba, individuālais es), „bios“" (dzīve, sociālā realitāte) un ,graphe“ (teksts, naratīvs)“ (BelaKrūmiņa 2004: 15). Pētniece norāda, ka tieši trešā pieeja ir tā, kurā „galvenā uzmanība tiek pievērsta dzīvesstāstam kā subjektīvi konstruētam tekstam, nevis reālistiskam dzìves atspoguḷojumam“ (turpat). Citās naratīva definīcijās arī īpaši ir akcentēts viedoklis, ka caur stāstījumu stāstītājs reprezentē savu būtību un sevi attiecībās ar citiem, ar vidi, kurā viņš dzīvo, - fizisko un psiholog̣isko telpu (Ochs, Capps 1996).

Pēdējais iepriekš tekstā pieteiktais pamatjēdziens, kura izpratnei ir nozīme šajā pētījumā, ir deiktiskās norādes (deixis), kas plaši aprakstītas pragmatikas teorijā (piemēram, Levinson 1983, latviešu valodā: Plaude 2004) un kā lingvistiskās analīzes paṇēmieni izmantotas gan tradicionālās valodniecības pẹtījumos, gan arī mūsdienās pārstāvētajā virzienā - diskursa analīzē. Deiktisko norāžu pamatā var būt personu vietniekvārdi, laika un vietas apstākḷa vārdi un citu vārdšksiru vārdi, kuri pilda ne tikai semantisko, bet arī pragmatisko funkciju. Deiktiskās norādes kalpo kā references uz noteiktu cilvēku vai sevis paša identitātes apzinātu vai neapzinātu uzsvēršanu, uz noteiktu vietu, laiku vai situāciju. Aiz šiem vārdiem stāv runātājam zināmais, dažbrīd īpaši sarunā uzsvērtais situācijas konteksts jeb konsituācija; ja šīs fona zināšanas ir pazīstamas arī klausìtājam, tad viņš dekodēs teikto; ja nē - vārdu nozīme konkrētajā runas situācijā paliks neatšifrēta. Šajā pētījumā naratīva dekodēšanā visvairāk ir palīdzējusi vietas (telpas) un laika, nedaudz arī - personas deiktisko norāžu pamanīšana un nozìmes interpretācija. 


\section{Naratīva analīze}

Naratīvs „lingvistiskajos, sociolingvistiskajos un diskursa analīzes pētījumos ir bijis uzmanības centrā pēdējo 40 gadu laikā" (Gimenez 2010: 198). Humanitārajās zinātnēs kopumā naratīva analīze ir izmantota, lai pētītu sociālo fenomenu atspogulojumu individuālajos stāstos, savukārt lingvistiskie rīki ir l̦āvuši precīzāk un detalizētāk atklāt gan eksplicīi pausto nozìmi, gan arī to, kas pateikts starp rindām, netieši jeb implicēti.

Šajā pētījumā naratīva (pamatā divu stāstịjuma daḷu, sk. 3. nodaḷāā) analīze ir balstìta modelī, kura ietvaru veido trīs galvenie komponenti: 1) stāsts (naratīvs); 2) stāstītāijs (kā viņš̌/-a stāstījuma laikā konstruē savu identitāti) un 3) pats stāstī̌sanas process, stāstījums (the tale - the content of the story and its form, the teller-the person through whose eyes we hear the tale and the telling or act of narration, vairāk sk.: Cheshire 2000: 236). Turklāt naratīva analīzē pētniekam nozīmīgi ir pamanìt tādu īpašu notikumu, atgadījumu, dzivē izšksirošu brīžu (critical events) pieminēšanu, kuri mainījuši stāstītāja ierasto dzìves ritmu, likuši uz pasauli paraudzīties citām acìm (Webster, Mertova 2007). Savukārt pats stāstīšanas process jeb stāstījums (trešais modeḷa komponents), tajā izmantotie paralingvistiskie līdzekḷi (runas intonācija, tonis, noteiktu morfēmu vai vārdu, izteikumu uzsvēršana ar balss intonācijas palīdzību), kā arī neverbālie līdzekḷi (ķermeņa kustības, sejas mīmika, žesti u. tml.) piešķir stāstījuma saturam papildnozīmi un konotāciju vai pat modificē verbāli pausto nozīmi (Bezemer, Jewitt 2010).

Tâlāk iegūtie pētịjuma dati tiks analizēti pēc iepriekš pieteiktā naratīva analīzes modeḷa.

\subsection{Stāsts}

Stāsta (tā visu četru daḷu) pamatā ir notikumi, kas risinājušies stāstītājas (sieviete, 2014. g. - 50 gadi) un lokālās kopienas dzīvē Latvijas un Igaunijas pierobežā (Valkā-Valgā) padomju laikā (20. gs. 80. gados), kad politiskā robeža starp Igauniju un Latviju nepastāvēja un līdz ar to cilvēki brīvi pārvietojās starp abām pilsētām, piemēram, strādājot Igaunijas pusē, bet dzìvojot Latvijā. Tālākie naratīva notikumi saistās ar 90. gadu sākumu - abu valstu neatkarības atjaunošanas laiku, kad atjaunota tika arī starpvalstu robeža. Pavisam nedaudz stāstījumā ienāk arī 21. gs.: Latvijas un Igaunijas pievienošanās Eiropas Savienībai un vēlāk - Šengenas zonai, kad fiziskā robeža starp valstīm (ar pasu kontroli uz robežas) atkal tika atcelta.

Visa analizējamā naratīva pamatā par kritisko, izšksirošo notikumu (critical event) respondentes un vietējo cilvēku dzīvē var uzskatīt robežkontroles atjaunošanu 1990. g. un sekas, ko vēlāk, 90. gados, tā izraisīja Valkas un Valgas iedzīvotāju ikdienā. Respondente (Valkas iedzīvotāja) 90. gadu vidū un otrajā 
pusē Valgā vadīja Bērnu un jauniešu radošo studiju - deju grupu, kurā piedalìjās kā Latvijas, tā Igaunijas puses bērni. Viņu ikdiena saistījās ar regulāru pāreju no Valkas Valgā un otrādi: bērni no Latvijas uz mēǵinājumiem gāja uz Valgu, savukārt Valgas bērni bieži bija manāmi Valkas pusē. Situācija mainīās ar robežkontroles punkta atjaunošanu, turklāt — no vietējo iedzìvotāju perspektīvas - tas notika pēkšņi, nepaspējot rast kādu risinājumu tieši šajā abu valstu perifērijā:

(1) Nu tas bija kaut kādi devin̄desmit sestais, septìtais. (--) Vienkārši mums notika tā, ka vienkārš̌i Rìgā, Tallinā pieñēma lēmumu (-), un tas lēmums stājās spēkā trīs dienu laikā, un (--) vispār neatkarīgi no tā, kur cilvēess strādā, kur nestrādā, kurā pusē. Pieñèma lèmumu, ka jāmaksā, cik tur bij tie repšiki, manuprāt, divdesmit, ejot pāri robežai. Es vairs neatceros. Vienkārši pieñèma lèmumu, ja tu gribi iet pāri robežai, jāmaksā nauda, nāc atpakal, jāmaksā nauda (-) un, ja cilvēki strādā (-) katru dienu, cilvēkam burtiski uz dienu bija jāaiziet no darba. TAD vienā jaukā dienā pieñèma lèmumu par šìm te (-), par tiem (---) à, par vecāku aţ̦aujām (--). Ka bez vecāka atlaujas nedrìkst iet, ka bērns nepilngadīgs, pāri robežai, ja.. VISS, neatkarīgi no tā, ka viss notiek pāri robežām, ka bērni staigā uz mèóinājumiem, mums piedevām vèl tajā laikà bij jābrauc uz Rìgu uz televīziju uz ierakstu, sestdienā. VISS, mums nevienam (---), nu, kur tu dabūsi pie notāra (--). Ceturtdienā pieñem lēmumu, viss, tu netiec pāri robežai. (054M)

Naratīva autores apmēram pirms 20 gadiem piedzìvotais atklāi problēmas, kas Latvijas-Igaunijas pierobežā dzīvojošajiem cilvēkiem radās pēc robežkontroles atjaunošanas. Šajā stāstījuma fragmentā četras reizes atkārtojas frāze „(vienkārši / vienā jaukā dienā) pieņēma lēmumu“; lai gan darbības vārds ir lietots darāmajā kārtā, darītāis nav minēts, sākumā vispārīgi pasakot „Rīgā, Tallinā'. Noteiktas frāzes atkārtojums liecina par emocionalitāti, par pārdzīvoto un par bezspēcību, jo tur (centrā - galvaspilsētās) kāds (?) nav iedomājies, kā šāds lēmums pēkšņi varētu skart perifērijā dzìvojošo (Valkas un Valgas) iedzìvotāju ierasto ikdienas rutīnu. Adverba vienkārš̌i (mums notika tā / pieñēma lèmumu) atkārtotais lietojums arī netieši norāda uz lielo plaisu starp lēmumu pieņēmējiem kaut kur centrā un vienkāršo cilvēku kaut kur abu valstu pierobežāa kuru šādi lēmumi skar tieši, paralizējot ierasto ikdienas ritmu. Arī vispārinājums, kas ar lielu uzsvaru izteikts ar vārdu VISS (transkripcijā lietoti lielie burti, jo runātāja šo vārdu izrunāja, īpaši to uzsverot), simboliski akcentē ierastās dzīves rutīnas apstāšanos, punkta pielikšanu noteiktam dzīves posmam, ko sociopolitiskās pārmaiņas ir ienesušas indivīda ierastajā ikdienas ritmā.

Iepriekšs (sk. 3. nodalıu) minētais translokalitātes jēdziens un tam raksturīgās perspektīvas (g̊geogrăfiskā jeb telpiskā un sociālā - cilvēku dzīves telpa) tieši atklājas šajā (1) transkriptā, proti, kā, pārejot no vienas teritorijas otrā, 
pierobežā cilvēki organizē savu sociālo dzìvi un mijiedarbību. Interesanti arī vērot darbības vārdus, kuri lietoti translokalitātes izteikšanai. Tā kā vēsturiski tā ir bijusi viena pilsēta, kas 1920. gadā sadalìta starp jaunizveidotajām Latvijas un Igaunijas valstīm, tas atspoguḷojas arī stāstījumā: cilvēki nebrauc vai neškēêrso robežu, bet vienkārši iet pāri / staigā: ar citiem ejot pāri robežai; ja tu gribi iet pāri robežai; bez vecāka ațaujas nedrīkst iet pāri robežai; bērni staigā uz mèóginājumiem. Savukārt uz Rīgu brauc - lai gan viena valsts, tomēr lokālā identitāte mês (mums notika tā ieklaui problēmas, kas skāra gan Valkā, gan Valgā dzīvojošos) izskan spēcīgāk nekā valstiskā (interpretējot stāstījumu: tur - galvaspilsētās - tiek pieņemti mūsu dzīvi apgrūtinoši lēmumi). Arī citi pētījuma laikā gūtie dati atklāi šìs valodas lietojuma īpatnības, piemēram, arī citas respondentes stāstījumā $(060 \mathrm{M})$ verbi iet un braukt netiek diferencēti, stāstot par došanos uz Somiju (Mīlāāa à àrstu nodarbība Igaunijā ir iet projām uz Somiju. jā, (---) un es domāju, ka es nemeloju, viena latviešu ārste taisās tūlìtās, tūlìtās iet uz Somiju).

Interesanti stāstījumā (1) vērot, kā noteiktas g̊eogrāfiskās telpas šķērsošana (translokalitāte) tiek raksturota, izmantojot laika deiktiskās norādes, piemēram, TAD vienā jaukā dienā, kas apliecina laiktelpas konceptuālo vienotību. Stāstījuma sākums atgādina universālas stāstījuma pazīmes, kuras raksturīgas arī vēstītāja folklorai. Tas savukārt pierāda metodoloǵijas nodalạa minēto apgalvojumu, ka naratīvs nav realitāte, tas ir subjektīvi konstruēts stāsts, kurā spēcīgi atklājas paša stāstītāja identitāte.

\subsection{Stāstītājs}

Analizējot stāstītājas naratīvu, tā valodu, personu deiktiskās norādes, var secināt, ka pamatā viņa sevi reprezentē daudzskaiț̣a pirmās personas mès formā (mēs ar savu audzēkni; mès ar draudzeni; mès ar vienu mazo dejotäju; mès te dzī̄ojam uz robežas; tā mēs te dzīvojam; mums visu laikā somā pases u. c.), turklāt dažreiz ar vietas deiktisko norādi netieši uzsverot translokālo identitāti: nu un šādi te mums, Valgas pusē .. . Stāstījumā dominē kā translokālā, tā arī lokālā identitāte, kura atseviškşos naratīva fragmentos (īpaši izšksirošo notikumu aprakstā - 90. gadu sākumā un vidū, abām valstīm atgūstot neatkarību) tiek papildināta ar etniskās piederības uzsvēršanu. Tās ir retas reizes stāstījumā, kad eksplicīti, no ārpuses (pašam negribot), tiek uzsvērta etniskā piederība (es - latviete), lai norādītu, ka kāds nav savējais. Naratīvs atklāj, kā stāstītāja ar skumju smaidu uzsver pēkšņi pierobežā parādījušos savējie-svešie apzīmējumu, kad svešais Latvijas pusē tika attiecināts uz igauņiem, Igaunijas pusē-uz latviešiem un abās pusēs - uz krieviem. Tāpat īpaša nozīme šajā kontekstā kḷūst arī telpas deiktiskajām norādēm: mūsu pusēe-tajā pusē. 
(2) Nu tas jau ir pavisam garš stāsts (-). Tā studija [bērnu deju studija] ir tāda, ka deviñdesmit piektajā gadā (--) Igaunijas interešu skolā izmeta no darba visus latviešus un un (-) krievus, paṇēma kultūras centrā darbā tikai igauņu pasniedzējus. Un mēs ar draudzeni, man draudzene ir Marina, krieviete, un es - latviete, un mēs nodibinājām studiju „„oy“, bērnu radošo studiju, jo mūs izmeta no darba (---). Nu, man pateica: Ina, es tevi nevaru pieñemt darbā, tāpēc ka tu esi latviete .. . Tā bija tāda politika deviñndesmito gadu sākumā. Mūsu pusē arī meta igauņus no darba ārā un krievus. Un tajā pusē meta ārā latviešus un krievus (smejas). Un, ja, vienkāršii, nu (---) (ar sāpēm) bija tas brīdis, kad valstis kḷuva brīvas un kad bija tikai savēiie. (054M)

Stāstītājas emocionalitāte un attieksme pret pēkšņajām izmaiņām pierobežas iedzīvotāju dzīvē ir vērojama, pamanot stāstījumā lietotos lingvistiskos un paralingvistiskos līdzekļus. Par lingvistiskajiem (diskursa) marķieriem var uzskatīt gan naratīva ievada formulas lietojumu (nu tas jau ir pavisam garš stāsts), gan arī atkārtotu ar negatīvu konotāciju iesaistītā verba (iz)mest no darba (ārā) lietojumu. Turklāt stāstījumā neparādās darītājs / izpildītājs - persona ir abstrakta, darbības vārdi izmeta (no darba); meta ārā; (man) pateica funkcionē kā bezpersonas verbi. Tas naratīvā nepārtraukti, netieši rada sajūtu par mēs, Valkas-Valgas iedzìvotāji (te, pierobežā, perifērijā, tālu no centra), un kāds (bezpersoniski), kurš kaut kur tur augšā pieņem lēmumus, kuru sekas pārtrauc cilvēku ierasto ikdienu.

Emocionalitāte izpaužas arī runātājas neverbālajā uzvedībā (2): pauzēs starp teikumiem vai viena teikuma vidū, sejas izteiksmē, ķ̣ermeņa valodā, smiekliem mijoties ar sāpju izteiksmi sejā. Tie ir paralingvistiskie līdzekḷi, kas kopā ar stāstītājas izmantotajiem lingvistiskajiem līdzeklịem piešķir stāstījumam gan l̦oti personisku noskaņu, gan sociotelpisko dinamiku, kā arī minēts naratîva teorijās: caur stāstījumu stāstìtāis reprezentē pats sevi, savu būtību un sevi attiecībās ar citiem. Tāpat caur stāstījumu tiek reprezentēta arī vide, kurā stāstītāis dzìvo, - fiziskā un psiholog̣iskā telpa (sk. iepriekš 3. nodaḷu).

Neitrālāka attieksme ir jaušama, atstāstot notikumus, kuri bijuši tālākā pagātnē un kuri nav saistīiti ar eksistenciāliem dzīves jautājumiem. Lai arī tajos līdzịgi kā 2. naratīva ekstraktā ir sastopams savèjā-sveša $\bar{a}$ pretstatīijums, tomēr stāstījumā vērojama neliela humora un ironijas pieskaņa:

(3) Astoñdesmit devītajā gadā, kad viss bija uz taloniniiem, ziepes un viss kaut kas šitāds, nu tad, kad mēes gājām Igaunijā iepirkties, tad arī latviski nedrīkstēja runāt. Tad labāk nerādìt, kas tu esi par tautību, labāk par igauni izlikties (---). Jā, tāda nu ir tā realitāte. Tas ir nepolitkorekti, ko es runāju, bet tā bij tā realitāte. (054M) 
Tādi izteikumi kā Igaunijā .. latviski nedrīkstēja runāt; labāk par igauni izlikties atspoguḷo îpašo translokālo situāciju Valkas-Valgas pierobežā, jo daudziem padomju periodā Latvijā dzìvojošiem cilvēkiem atmiņā vēl ir stāsti - ieteikumi: braucot uz Igauniju, tikai nerunājiet krieviski, tad jau labāk vismaz nedaudz latviski un tad krieviski, lai saprot, ka esat no Latvijas. Šādi atmiņu nostāsti, kas izauguši no individuālajiem dzìvesstāstiem, no vienas puses, atklāj apzīmējuma savējais-svešais saasināto uztveri dažādos vēsturiskajos periodos, no otras puses - norāda uz šo apzīmējumu lietojuma dinamiku noteiktā laiktelpā. Padomju iekārtas beigu posmā, kad ekonomiskais sabrukums atbalsojās garajās rindās pie veikaliem un deficītā, Valgā arī latvieši tika uztverti kā svešie, jo bija vistuvākie konkurenti uz ikdienas sadzīvei nepieciešamajām precēm. Savukārt tālāk no Latvijas-Igaunijas robežas šajā pašā laika periodā Igaunijā par svešajiem tika uzskatīti nevis latvieši, bet krievi.

\subsection{Stāstījums (naratīva akts)}

Kā jau iepriekš tika minēts, respondentes stāstījums, tajā lietotie valodas izteiksmes līdzekḷi, stāstījuma sākumā vai vidū lietotie diskursa marķieri (piemēram, jā, tāda nu ir tā realitāte), bet jo īpaši stāstịjuma ievada, turpinājuma un nobeiguma formulas atgādina kādu no vēstījuma folkloras žanriem. Tas liecina, ka naratīva analīzē būtiska nozìme ir ne tikai stāstījumā paustā satura izpētei, bet arī paša stāstī̌sanas procesa aplūkošanai. Tā padziḷ̂ināta analīze apstiprina dzīvesstāsta kā subjektīvi konstruēta teksta, kas nav aplūkojams kā analogs objektīvajai realitātei, konceptuālo veidolu.

Šì pètījuma kontekstā ir pamanāms, ka naratīva autores stāstīiums atgādina pasakas vai teikas tekstu, piemēram, izmantojot vēstījuma folklorā lietotās laika deiktiskās norādes: vienreiz vakarā mēs ejam (pasakas sākuma formula), $T A D$ vienā jaukā dienā (pasakas turpinājums) u. tml. Šie vēstījuma elementi tiek izmantoti arī kā teksta koherences līdzekḷi, norādot uz pakāpenisku sižeta attīstību, tuvojoties stāstījumā noteiktam kulminācijas punktam.

Tāpat, analizējot naratīva autores stāstīšanas procesu, jāuzsver stāstījuma ieraksta laikā pamanìto stāstītājas vēlmi uzturēt dialogu ar klausìtāju (lai gan pašam stāstījumam piemita gandrīz monoloǵisks raksturs). Tas izpaudās, gan izmantojot neverbālos līdzekḷus (dažbrīd īpaši skatoties acīs, žestikulējot u. tml.), gan arī respondentes refleksijās par pašas teikto, piemēram, $j \bar{a}$, tāda nu ir tā realitāte; tas ir nepolitkorekti, ko es runāju, bet tā bij tā realitāte (3) vai-tas ir tas, ko es nemaz nedrīkstu stāstīt:

(4) man viena meitene dejotāja bij, kurai tềvs bij izbijušais armijnieks (--). Tas ir tas, ko es nemaz nedrīkstu stāstīt, ja. Es ar viṇu kopā lecu pāri grāvim robežas, jo viṇa nedrīkstēja iet pāri robežai pēkšn, vienā jaukā dienā. (054M) 
Pètījumā analizētajā naratīvā bez iepriekš minētajām tam raksturīgajām iezīmēm tika pamanīta vēl kāda lingvistiski interesanta parādība - latviešu valodā, kurā notika stāstījums, stāstītāja dažbrīd iekḷāva arī citu valodu vārdus vai izteikumus.

Tālāk stāstījuma analīzē tiks pievērsta uzmanība šai kodu variēšanai viena runas akta laikā (translanguaging, vairāk sk. 3. nodạ̧ā), lai atbildētu uz otru šajā pètījumā izvirzìto jautājumu: kurās situācijās un kā naratīvā ir vêrojamas ne tikai translokalitātes izpausmes, bet arī valodu robežu šķêrsošana.

Visās respondentes naratīva daḷās, ne tikai šajā pētījumā aplūkotajās (sk. iepriekš 3. nodaḷā), kodu variēšana tika novērota viena izteikuma robežās, iestarpinot kādu vienu vārdu vai izteikumu.

Viena citas valodas vārda iestarpināšanu pētāmā naratīva kontekstā var interpretēt kā translokalitātes savdabību pierobežā: respondente, kurai dzimtā valoda ir latviešu valoda, nerunā igauņu valodā, bet zina vārdus, kuri nozīmīgi viņas profesionālās dzīves kontekstā:

(5) Tajā laikā Latvijā tāda modernā deja .. . Kā tagad sauc „laikmetīgā deja“ Latvijā saucas, Igaunijā sauc vabatanc. (054M)

Arī vietu nosaukumi (pilsētas vai apriņķa), runājot par Igauniju, tika minēti igauņu valodā, ievērojot igauņu valodas izrunu un netulkojot nomenklatūras vārdus latviski, piemēram, apriņ̧̧is, pilsēta:

(6) Un tad mums tiešām igauņu valodas profesore (-) mācīja nometnē to valodu (smaida) un (--) vina arī mācīja valodas toreiz tur Ida-Virumā, tur Narvas, jā, visiem šitiem (-) Silamē .. . (056M)

Tāpat tika novērotas arī runas situācijas, kad stāstījumā autore iekḷāva kādu angḷ̆u valodas vārdu. Nav iespējams objektīvi pamatot šo procesu, vienīgi transkribēto materiālu datu bāzē var pamanìt, ka kāds angḷ̣u valodas vārds parādās, respondentei stāstot par mūsdienām.

Klausoties un vērojot stāstīšanas procesu, var saskatīt atškirirības, kad stāstījumā tiek variēts ar krievu valodas un kad — ar angḷ u valodas vārdiem: krievu valodas vārdi vai izteicieni ir lietoti kā neatņemama dzīvesstāsta daḷa, atstāstot kādu konkrētu situāciju, citējot pašas teikto vai dialoga partneri, pieškịirot stāstītajai situācijai autentiskumu un - kas šķiet būtiski - it kā nepamanot šo pārslēgšanos uz krievu valodu, ne ar verbāliem, ne neverbāliem līdzekliem nekomentējot šo procesu metalīmenī. Savukārt angḷ u valodas vārdu iestarpināšanu pavada apzināta stāstītājas neverbālā reakcija: smaids, tāds kā apmulsums, neveiklïba, ka ir notikusi kodu variēšana, piemēram:

(7) atsevišķ setingi (smejas) ir, kur dzird igaun,u valodu šeit, Valkas pusē, Mego, un igauṇi iet skriet uz mūsu mežu, mums ir mežs foršs, estrāde. 
Mums ceturtdienās ir Optimists tas saucamais, visa pilsēta skrien, un tur igauņi ar piedalās. Vienkārš̌i tāda tautas skriešana .. . Jā, tā var dzirdēt gan no sportistiem, gan no pircējiem igauņu valodu. (054M)

Salīdzinājumam arī kāds piemērs ar latviešu-krievu valodas pamīšus lietojumu. Pirmajā piemērā (8) respondente stāsta par situācijām robežas kontroles punktā; atceroties dialogu ar robežsargu, viņa neapzināti pārslēdzas uz krievu valodu:

(8) Mums visu laiku somā pases (--). Tur pat bija tā, ka tur bez jumtina, uz robežas jumtina nav, atver tavu pasi, skatās, tur snieg iekšā sniegs, līst iekšà lietus, aiztaisa ciet, un tu ej pāri, pases mums bija tādas kā dzēšlapas vienkārš̌i (-). Kamēr arī sataisīja to robežu, jumtiņus uztaisìja pāri. Tad tikai robežsargs atvēra, skatos, sasnieg sniegs, es tikai: Netaisiet ciet!', ne zakrivajte, ne zakrivajte, ja, lai es pēc tam noslauku ... (054M)

Otrajā piemērā (9) ir redzams, kā viena runas akta laikā ir iekḷauts citātsfrāze, lai precīzāk atklātu (bieži vien) situācijas absurdumu:

(9) Pirmo diktātu, es atceros, tā man tāda bèrnības trauma, skolotāja diktēja: zajac točka, derevo točka. Un es tā arī rakstīju: zajac točka, derevo točka, un piedevām es rakstīju nevis točka, bet počka, jo es nemācēju (smejas). (054M)

Lai arī 9. ekstraktā krievu valodas apguves procesam runātāja ir veltījusi semantiski spēcīgu apzīmējumu (bêrnības trauma), tomēr neverbālā uzvedība (sirsnīgi smiekli) un stāstījuma turpinājums (par pagalmā nepiespiestā gaisotnē apgūto krievu valodu un brīnišksịgo krievu valodas skolotāju, kā rezultātā varu skaitīt Puškinu no galvas šobrīd, Jeseñinu un vēl (smejas) visādus tur kara laika dzejoḷus tur) liecina par pozitīvu lingvistisko attieksmi gan pret krievu valodu, gan arī kultūru.

Nodalas noslēgumā vēl pēdējais citāts, kurā stāstìtāja lepni atklāj vienkāršā cilvēka, kurš dzīvo pierobežā, perspektīvu salīdzinājumā ar likumu pieņēmējiem galvaspilsētās vai ārpus Latvijas un Igaunijas:

(10) Visus 20 gadus tur nāk no Latvijas puses bèrni, attieksme pret to ir bijusi dažāda, tikai tad, kad ir bijis Šengen, kā mana draudzene saka: Šengen (smejas), kad ir bijusi Šengenas zonas atklāšana, tad visi saprata, ka tāda studija [bērnu deju studija, kurā darbojas bērni gan no Latvijas, gan no Igaunijas] ir vajadzīga. (054M)

Respondente mazliet ironiski stāsta, ka viņas bērnu deju studija tika aicināta uzstāties par godu Šengenas zonas atklāšanai, lai simboliski demonstrētu 
brīvo robežu starp abām valstīm un abām pilsētām. Šim faktam nacionālajā un starptautiskajā līmenī tika pieškirta liela uzmanība un vērtība, lai gan viņa jau daudzus gadus iepriekš šādu projektu (tikai lokālajā līmenī) ir iniciējusi un realizējusi un 90. gados bijusi spiesta savu darbu pārtraukt.

\section{Secinājumi}

Atgriežoties pie raksta ievadā formulētajiem pētniecības jautājumiem, var secināt, ka pētījumā analizētais naratīvs atspoguḷo galvenās idejas, kas aprakstītas teorētiskajā literatūrā par naratīvu un tā analīzi, par translokalitāti un tai raksturīgajiem procesiem indivīda un sabiedrības līmenī. Naratīva autore, stāstot par savu sociālo dzìvi, mijiedarbību ar lokālās vides pārstāvjiem pierobežā, Latvijas un Igaunijas pusē, netieši uzsver translokalitātes g̊geogrāfisko un sociālo perspektīvu. Veids, kā šajā g̊eogrāfiskajā telpā viņa ir organizējusi savu dzìvi un kā viņa par to stāsta, ḷauj ieraudzìt un raksturot stāstītājas attiecības ar fizisko vidi (Valku-Valgu noteiktā vēstures periodā kā dvīṇu pilsētām un citā - kā divu neatkarīgu valstu sting rām robežpilsētām) un arī viņas refleksijas par savu individuālo emocionālo telpu.

Naratīva analīze, ieklaujot tajā personas, vietas un laika deiktiskās norādes kā nozīmīgus lingvistiskos marķierus, atklāj, ka īpašais pagrieziena punkts (critical event) stāstītājas dzīvē ir bijis robežkontroles atjaunošana, abām valstīm atgūstot neatkarību. Autore neapšauba neatkarības atjaunošanas nepieciešamību, bet uzsver tādu lēmumu absurdumu, kuri ir pieņemti kaut kur augšă - Rìgā un Tallinā, acīmredzami neapzinoties to ietekmi uz pierobežas teritorijā dzìvojošo cilvēku ikdienas dzìvi. Stāstījumā lēmumu pienēēmēju balsis (voicing) eksplicīit nav pārstāvētas, subjekti nav minēti, līdz perifērijai, pierobežai viņu vārdi nav atnākuši (stāstịjumā lietoti bezpersonu verbi: vienā jaukā dienā pieñēma lèmumu). Otra atziņa, kas izriet šîs pašas konsituācijas sakarā, ir: abu valstu neatkarības un politiskās robežas atjaunošana sadalīja translokālajā teritorijā dzīvojošo kopienu savējos un svešajos (kad valstis bija brīvas un bija tikai savējie), uzsverot abu valstu titulnāciju (attiecīgi - latviešu un igauņu) pārākumu pār citiem.

Atbildot uz otro pētījuma jautājumu, var teikt, ka kodu variēšana (translanguaging) nav izteikta pazīme analizētajā naratīvā. Respondente tikai reizēm iekḷauj stāstịjumā kādu frāzi vai vārdu citā valodā. Rakstā minētie transkriptu fragmenti, kā arī tie, kas šajā rakstā netika analizēti, atklāj, ka stāstītāja sava stāstījuma laikā šḳērso vienas valodas robežas divējādos veidos: 1) iekḷaujot stāstījumā tikai atseviškşus igauņu, ang̣̣ı vai krievu valodas vārdus; 2) lietojot viena runas akta laikā kādas frāzes - citātus krievu valodā. Šis konstatējums savukārt lạuj izteikt pieņēmumu, ka pārslēgšanās no viena koda uz otru vairāk nekā viena vārda līmenī notiek tad, ja runātājs izjūt lingvistisko komfortu valodās, kuras runas situācijā lieto pamīšus (šajā pētījumā: latviešu un krievu 
valodu). Savukārt viena citas valodas vārda iestarpināšana stāstījumā neliecina par attiecīgās valodas kompetenci, bet - par cilvēku (valodu) kontaktiem noteiktā ǵeogrāfiskajā areālā (šajā pētìjumā: latviešu un igauņu valoda) un noteiktā sociopolitiskā situācijā (padomju laikos - krievu valoda, Latvijai un Igaunijai pievienojoties ES un vēlāk Šengenas bezrobežu zonai - angḷı valoda). Šādās situācijās koda maiṇu var raksturot kā stilistisko marķieri konsituācijas autentiskuma paspilgtināšanai.

\section{Naratīva transkripcijā lietotie simboli}

$\begin{array}{ll}\text { Pauzes } & (-)<0,5 \text { sek. } \\ & (--) 0,5-1 \text { sek. } \\ & (---)>1 \text { sek. } \\ \text { Skalıums } & \text { LIELI BURTI - izteikts ar uzsvaru } \\ \text { Citi apzīmējumi } & . .- \text { izlaista intervijas teksta dạ̣a } \\ & {[\text { teksts }] \text { - pētnieka precizējums }} \\ & (\text { emocijas }) \text { - ekstralingvistiskie līdzekḷi }\end{array}$

\section{Literatūra}

Bela-Krūmiña, Baiba. 2004. Dzīvesstāsti kā sociāli vêstījumi. Promocijas darbs doktora grāda iegūšanai sociolog̣ijā, sociālās antropolog̣ijas apakšnozarē. Rīga: Latvijas Universitāte. Pieejams: http://www.dzivesstasts.lv/admin/ content_files/Bela_DISERTACIJA.pdf

Bezemer, Jeff and Jewitt, Carey. 2010.

Blackledge, Adrian and Creese, Angela. 2010.

Cheshire, Jenny. 2000. Multimodal Analysis: Key Issues. Litosseliti, Lia (ed.). Research Methods in Linguistics. London, New York: Continuum International Publishing Group, 180-197.

Multilingualism. A Critical Perspective. Bloomsbury Academic.

The telling or the tale? Narratives and gender in adolescent friendship networks. Journal of Sociolinguistics 4/2, 234-262.

García, Ofelia. 2009. Bilingual Education in the 21st Century: A Global Perspective. Malden, MA and Oxford: Basil/Blackwell.

García, Ofelia and Wei, Li. 2014.

Translanguaging. Language, Bilingualism and Education. Palgrave Macmillan UK.

Gimenez, Julio C. 2010.

Greiner, Clemens and Narrative Analysis in Linguistic Research. Litosseliti, Lia (ed.). Research Methods in Linguistics. London, New York: Continuum International Publishing Group, 198-216.

Sakdapolrak, Patrick. 2013. Translocality: Concepts, Applications and Emerging Research Perspectives. Wiley Online Library. Pieejams: https://onlinelibrary. wiley.com/doi/full/10.1111/gec3.12048

Latvijas Republikas Ārlietu ministrija. 2007.

Latvija pievienojas Šengenas zonai. Pieejams: https://www.mfa. gov.lv/aktualitates/zinas/24752-latvija-pievienojas-sengenas-zonai 
Lazdiņa, Sanita. 2017.

Levinson, Stephen C. 1983.

Mazak, Catherine M. and

Carroll, Kevin S. (eds). 2017.

Ochs, Elinor and Capps,

Lisa. 1996.

Plaude, Ilze. 2004.

Valkas novada dome. 2014.

Webster, Leonard and

Mertova, Patricie. 2007.
Vai tikai mūzikā ir polifonija: valodu izglītības plānošana glokalizācijas procesu kontekstā. V. L̇ubkina, S. Ušča (red.). Izglìtības reforma vispārizglītojošajā skolā: izglìtības satura pētījumi un ieviešanas problēmas. Rēzekne, Rēzeknes Tehnoloğiju akadēmija, 40-53.

Pragmatics. Cambridge University Press.

Translanguaging in Higher Education. Beyond Monolingual Ideologies. Bristol: Multilingual Matters.

Narrating the self. Annual Review of Anthropology 25, 19-43. Pieejams: http://www.sscnet.ucla.edu/anthro/faculty/ochs/articles/ Ochs_Capps_1996_Narrating_the_Self.pdf

Pragmatika. Rīga: Latvijas Universitāte.

Valkas novada attīstības programma 2010.-2016.gadam. Pieejams: http://valka.lv/wp-content/uploads/2014/09/esos_sit_galiga.pdf

Using Narrative Inquiry as a Research Method: An Introduction to Using Critical Event Narrative Analysis in Research on Learning and Teaching. Taylor \& Francis.

Sanita Lazdina

Rēzeknes Tehnologíiju akadèmija

Atbrīošanas aleja 115

LV-4601 Rēzekne, Latvija

sanita.lazdina@rta.lv

\title{
SUMMARY
}

\section{"May the Result of Wishful Thinking Be a United City" - Narratives about Life between Two Political Eras in the Twin-town of Valga-Valka}

\author{
Sanita LAZDIN̦A
}

This paper reports research carried out during 2014 and 2015 in the border area of Latvia and Estonia, in the city of Valka-Valga which was one town throughout most of its history. Today, however, they are two towns separated by the state border. Most recently, the two towns have started to cooperate again more closely under the initiative One city, two states.

In this paper I have analyzed data from narratives provided by one of the interviewees, a pre-school teacher (F, 50 years old). These narratives provide an insight into the social life, languaging and identity in the translocal environment of the border area. Using the method of narrative analysis (Gimenez 2010), my analysis is based on the following research questions: How do the narratives represent translocality - i.e. how do they reflect life spaces and social interaction in a translocal territory in different times? How and in which situations does the narrator cross language boundaries?

Two critical events within these narratives were identified - incidents that reveal a change of the world-view by the story teller (Webster / Mertova 2007): the 1991 re-establishment of Latvian and Estonian independence and 2007, when border control was removed after both countries had joined the Schengen zone. 
As a theoretical background for a deeper analysis, the concepts of translocality and translanguaging were used. Translocality has two perspectives: geographical and social; it provides an overview of peoples' life spaces and ways of organizing their social networking and interaction in a translocal territory. Translanguaging in current sociolinguistic discourse denotes the transition from one language to another in a given speech situation. The process of translanguaging is characterized as the use of linguistic resources to create meaning in ways that do not always recognize language boundaries (Blackledge \& Creese 2010). My case study investigates translanguaging processes in this sense, i.e. switching from one language to another within a single conversation (e.g., Latvian-Russian, Latvian-Estonian, Latvian-English, Russian-English). 